\title{
Futbol Taraftarlarının Fanatiklik ve Lisanslı Ürün Satın Alma Düzeylerinin İncelenmesi
}

\author{
DOI: 10.26466/opus.726872
}

*

\author{
Çağrı İlk* - Selçuk Bora Çavuşoğlu** - Cemal Güler *** \\ * Öğr. Gör. Dr., Acıbadem Mehmet Ali Aydınlar Üni, Spor Bilimleri Fakültesi, İstanbul/Türkiye \\ E-Posta: cagriilk@gmail.com \\ ORCID: 0000-0003-0360-6545 \\ ** Doç.Dr., İstanbul Üniversitesi-Cerrahpaşa, Spor Bilimleri Fakültesi, İstanbul/Türkiye \\ E-Posta: boracavusoglu@windowslive.com ORCID: 0000-0003-4163-9655 \\ *** Arş. Gör., İstanbul Üniversitesi- Cerrahpaşa, Spor Bilimleri Fakültesi, İstanbul/Türkiye \\ E-Posta: cemal.guler@istanbul.edu.tr \\ ORCID: $\underline{0000-0001-6831-563 X}$
}

\begin{abstract}
Öz
Bu araştırmada futbol taraftarlarının fanatiklik ve lisanslı ürün satın alma düzeylerinin sosyo-demografik özelliklere göre incelenmesi amaçlanmaktadır.Araştırmamıza uygun örnekleme yöntemi kullanılarak \%61,3'ü (236) Kadın \%38,7'si (149) Erkek olmak üzere toplam 385 gönüllü futbol taraftarları katılmıştır. Araştırmada veri toplama aracı olarak birinci bölümde katılımcılara 9 soruluk Kişisel Bilgi Formu uygulanmıştır. İkinci bölümde ise Taşmektepligil, Çankaya ve Tunç (2015) tarafından geliştirilen dörtlü likert 13 maddeden oluşan "Futbol Taraftarı Fanatiklik Ölçeği" ve Kwon ve Armstrong (2002) tarafindan geliştirilmiş, Ayhan ve vd .(2017) tarafindan değişikliğe uğramış beşli likert 23 maddeden oluşan "Lisanslı Ürün Satın Alma Ölçeği" kullanılmıştır. Ölçek güvenirliğini test etmek için kullanılan iç tutarlılık katsayısı Futbol Taraftar Fanatiklik Ölçeği'nde .84, Lisanslı Ürün Satın Alma Ölçeği'nde ise 95 olarak bulunmuştur. Tanımlayıcı istatistiklerin yanında, verilerin normal dağgllım gösterip göstermediği belirlemek için Shapiro Wilks testiyle ölçülmüş ve normal dağılmadığııa karar verilmiştir. Bu analizler doğrultusunda parametrik olmayan Mann Whitney U ve Kruskal Wallis testleri, aynı zamanda ikili karşılaştırmalar için Spearman Korelasyon testi uygulanmıştır. Sonuç olarak cinsiyet, takım, ürün satın alma, sosyal medya kullanımı, maçları takip etme, sosyal medya platformların kullanımı ve ürün alma değişkenlerine göre fanatik olma ve lisanslı ürün satın alma da etkili olduğu tespit edilmiştir. Özellikle bu etkinin cinsiyet, lisanslı ürün satm alma ve maçları takip etme de daha yüksek olduğu sonucuna ulaşılmıştır.
\end{abstract}

Anahtar Kelimeler: futbol, fanatiklik, lisanslı ürün satın alma 


\title{
Investigation of Fanaticity and Licensed Product Purchase Levels of Football Fans
}

\begin{abstract}
In this study, it is aimed to investigate the fanaticism and licensed product purchasing levels of football fans according to their socio-demographic characteristics. A total of 385 volunteer football fans, $61.3 \%$ (236) Women, 38.7\% (149) Men, were participated by using the appropriate sampling method. In the research, 9 questions Personal Information Form was applied to the participants in the first section as a data collection tool. In the second part, the four-point Likert 13-item "Football Fan Fanaticism Scale" developed by Taşmektepligil, Cankaya and Tunc (2015) and the five-point Likert 23 item that was modified by Ayhan et al. (2017), developed by Kwon and Armstrong (2002), Licensed Product Purchase Scale "was used. The internal consistency coefficient used to test the scale reliability was found to be 84 on the Football Fan Fanaticity Scale and .95 on the Licensed Product Purchase Scale. In addition to the descriptive statistics, it was measured with the Shapiro Wilks test to determine whether the data showed a normal distribution and whether it was distributed normally. In line with these analyzes, the nonparametric Mann Whitney $U$ and Kruskal Wallis tests were applied, as well as the Spearman Correlation test for binary comparisons. As a result, it has been determined that gender, team, product purchasing, using social media, following matches, using social media platforms and being fanatical according to the variables of buying and buying licensed products are also effective. In particular, it was concluded that this effect was higher in sex, buying licensed products and following matches.
\end{abstract}

Keywords: football, fanaticity, buying licensed products 


\section{Giriş}

Modern futbolun ilk adımları 17.yy'da İngiltere'de atılmış, halk ve soylular tarafından büyük bir ilgi duyularak hızla gelişmeye başlamıştır (Tercüman, 1987). Ülkemizde ise futbol tarihine baktığımızda, 19. yy'ın son çeyreğinde oynanmaya başlandığını söyleyebiliriz. Osmanlı zamanında ise Selanik'te başlayan, gün geçtikçe de Bornova çayırlarına kadar uzanan bir öyküsü vardır. İlk futbol kulübünü İzmir'de İngilizler kurmuş, daha sonra İstanbul'a ulaşarak Kadıköy ve Moda çayırlarını etkisi altına alan bu salgın tüm kentin ilgisini çekmesiyle yayılmaya başlamıştır (TFF, 2020).

Futbol literatüründe seyirci, taraftarlık ve fanatiklik kavramları sıkça karşımıza çıkmaktadır. Birbirine benzer kavramlar olmasına rağmen, aralarında temel farklar olduğunu söyleyebiliriz. Seyirci “Bir spor karşılaşmasını sürekli izlemese de zaman zaman dikkatle takip eden kişi", taraftar ise 'Takımına ait müsabakayı, özel zaman ayırarak yoğun bir biçimde takip eden bireydir' (Jones, 1997). Fanatik ile taraftar arasındaki farka baktığımızda, fanatikler takımlarına daha fazla bağlıdırlar. Poyraz (2007), bu bağlılık biçimini, 'körü körüne, bağnaz' bir şekilde olduğunu ifade etmektedir. Futbol artık bir dünya sporu haline gelmiş, sosyal hayatta bile yerini almaya başlamıştır. Kulüplerin mağazalarında ürünlerini satması ve taraftarları peşinden sürüklemesi bunu kanıtlamaktadır (Aydın vd, 2007). Spor pazarlaması tanımının çok yönlü bir yapısı olduğunu düşünürsek, çeşitli tarihsel gelişmeleri vardır. Bu gelişmelerle birlikte hedef kitle grubuyla daha etkili iletişim kurulmaya başlanmıştır. Mark Mc Cormack ve onun ajansı, Uluslararası Yönetim Grubu'nun (IMG) 1960'lı yıllarda spor pazarlamacılığını başlattığı yaygın olarak kabul edilmiştir (Uslu ve Eroğlu, 2019). Küreselleşmenin artmasıyla beraber şirketler pazar paylarını, hedef kitlelerini arttırmak için çeşitli stratejiler geliştirmişlerdir. Bu duruma pazarlama stratejileri denmektedir (Çavuşoğlu, 2011). Spor pazarlaması bu stratejilerin arasında paya en fazla sahip olan sektörlerin başında gelmektedir. Spor pazarlamasının üzerinde durulan sporun kendisinin veya spor ürünlerinin pazarlanmasına vurgu yapılmaktadır. Spor ürünleri bu alandaki mal ve hizmetlerden oluşmaktadır. Tanımdan anlaşılacağı üzere sporun bir tüketim aracı olarak kullandığı ifade edilmektedir (Devecioğlu, 2017).

Spor pazarlaması kulüplerin en önemli işlevi haline gelmiştir. Spor sürekli kendini geliştiren, yenileyen bir sektördür. Spor sektörünün gelişmesiyle 
ürünlerde ve kulüp sayılarında artış meydana gelmektedir. Her yeni ürün, her yeni işletme rekabet demektir. Rekabet, bir kulübün veya spor işletmesinin tüketiciyi kazanmak için diğer kulüplerle faaliyet içerisine girmesidir (Argan ve Katırc1, 2008). Spor organizasyonlarında markaları spor ile birleştiren dünya çapında bir şirket olan Octagon EMEA başkanı Jeff Ehrenkranza'a göre her sene insanların maç biletleri için harcadığı rakam 52 milyar dolar olduğunu belirtmektedir (Donuk, 2019). Firmalar özellikle dünya çapında yapılan organizasyonlara sponsor olarak isimlerini duyurma çabası içine girmektedir. Spor pazarlamasında özellikle amaç, tutundurma aracı olarak sporu kullanarak mal ve hizmetlerin tüketicilere pazarlanmasıdır (Mullin vd., 1993).

Tüketici davranışları, bireylerin ihtiyaçlarını karşılayacağını düşündüğü ürün ve hizmetleri, değerlendirme, satın alma, kullanma ve sonrasında elden çıarma gibi fiziksel faaliyetlerin tümünü kapsayan karar verme sürecidir (Bozkurt, 2004). Spor pazarlamasında da kulüpler tüketicilerin davranışını anlamak ve takip etmek zorundadır. Tüketicilerin satın aldıkları ürünlere karşı oluşturdukları davranışa göre pazarlama stratejileri uygular ve hedef kitle sayısını arttırma amacını taşırlar. Pazarlama faaliyetlerini uygularken tüketicilerin davranışlarını etkileyen faaliyetler hakkında da bilgi sahibi olmak gereklidir. Akyüz (2009) çalışmasında tüketici davranışlarını etkileyen faktörleri; kültürel faktörler, sosyal faktörler, kişisel faktörler ve psikolojik faktörler olarak incelemiştir. Tüketiciler ihtiyaçlarını karşılamak için mal ve hizmetlerle ilgili birden fazla karar verir. Tüketiciler için beğendiği hizmet ve ürünü satın alması ona duyduğu ilgi ve öneme bağlıdır (Aslan ve Özbeyaz, 2019). Bu bilgiler doğrultusunda, çalışmamızın amacı, futbol taraftarlarının fanatiklik ve lisanslı ürün satın alma düzeylerinin sosyo-demografik özelliklere göre incelemektir.

\section{Yöntem}

Araştırmamızda, futbol taraftarlarının fanatiklik ve lisanslı ürün satın alma düzeylerinin sosyo-demografik özelliklere göre incelenmesi amaçlanmaktadır. İlişkisel tarama modeli kullanılarak yapılan çalışmamıza uygun örnekleme yöntemi kullanılarak \%61,3’ü (236) Kadın \%38,7'si (149) Erkek olmak üzere toplam 385 gönüllü futbol taraftarları katılmıştır. Araştırmamızın evrenini İstanbul'da yer alan futbol taraftarları oluşturmaktadır. Örneklemini ise 
2019 yılında yeni eğitim öğretime başlamış İstanbul Üniversitesi-Cerrahpaşa, Acıbadem Mehmet Ali Aydınlar Üniversitesi ve Esenyurt Üniversitesi'nde öğrenim gören futbol taraftarları oluşturmaktadır. Örnekleme, çalışma yaptığımız araştırma evreninden onun temsil ettiğine inanılan bir bölümün, çalışma evreni hakkında çıkarımlara ulaşmak için belirli yöntemler yoluyla seçilmesidir (Böke, 2017). Araştırma ölçeğin uygulandığı futbol taraftarları ile ulaşılan kaynaklarla, literatür çalışmaları ile sınırlıdır.

\section{Veri Toplama Araçları}

Çalışmamız iki bölümden oluşmaktadır. Birinci bölümde katılımcılara 9 sorudan oluşan Kişisel Bilgi Formu uygulanmıştır. İkinci bölümde ise, Veri toplama aracı olarak Taşmektepligil, Çankaya ve Tunç (2015) tarafından geliştirilen Likert tipinde hazırlanmış ve 13 maddeden oluşan "Futbol Taraftarı Fanatiklik Ölçeği" (FTFÖ) ve Kwon ve Armstrong (2002) tarafından lisanslı ürün satın almayı etkileyen faktörlere ilişkin kullanmış, Ayhan ve vd. (2017) tarafından uygun olarak değişikliğe uğramış “Lisanslı Ürün Satın Alma Ölçeği"nden yararlanılmıştır.

Kişisel Bilgi Formu: Katılımcılara cinsiyet, yaş, üniversite, takım, futbol maçlarını takip etme durumu, kitle iletişim aracı, ürün satın alma, sosyal medya takibi ve sosyal medya platformlarına ilişkin 9 soru içeren Kişisel Bilgi Formu uygulanmıştır.

Futbol Taraftarı Fanatiklik Ölçeği: Taşmektepligil, Çankaya ve Tunç (2015) tarafından geliştirilen ölçek, dörtlü likert tip (Kesinlikle katılıyorum, Katıl1yorum, Katılmıyorum, Kesinlikle Katılmıyorum), iki alt boyut ve 13 maddeden oluşmaktadır. Ölçeğin ilk 8 maddesi "Şiddete Yönelik Düşünce ve Eylem Eğilimi" ve son 5 maddesi "Kurumsal Aidiyet" alt boyutlarını kapsamaktadır. Ölçekten alınan minimum puan 13, maksimum puan 52'dir. Ölçek maddelerinin iç tuturlılık kat sayısı .84 bulunmuştur

Lisanslı Ürün Satın Alma Ölçeği: Kwon ve Armstrong (2002) tarafından lisanslı ürün satın almayı etkileyen faktörlere ilişkin kullanmış oldukları ölçek beşli likert ( Tamamen Katılıyorum, Katılıyorum, Fikrim Yok, Katılmıyorum, Tamamen Katılmıyorum) , beş alt boyut ve 23 maddeden oluşmaktadır. Ölçeğin ilk 8 maddesi "Takıma Destek Motivasyonu”, 4 maddesi "Takımla Öz- 
deşleşme Motivasyonu", 4 maddesi "Kullanım Hazzı Motivasyonu", 4 maddesi "Sosyal Cazibe Motivasyonu" ve son 3 maddesi "Alışveriş Hazzi" alt boyutlarını kapsamaktadır. Ölçek maddelerinin iç tutarlık kat sayısı .95 bulunmuştur.

\section{Verilerin Analizi}

Çalışmamızda elde edilen veriler SPSS 25.0 paket programı kullanılarak analiz edilmiştir. Demografik özelliklere ait tanımlayıcı istatiksel sonuçlar için frekans analizi yapılmış, hipotez testleri için ise nonparametrik testlerden Mann Whitney U testi ve Kruskal Wallis, iki ölçek alt boyutları arasındaki ilişki için spearman korelasyon testi ve Cronbach alfa güvenirlik testleri uygulanmiştır.

\section{Bulgular}

Tablo 1. Futbol Taraftan Fanatiklik Ölçeği ve Lisansh Ürün Satın Alma Ölçeğine ait alt boyutlarn Cronbach's alfa kat sayılarn

\begin{tabular}{lll}
\hline Alt Boyutlar & Madde Sayısı & Cronbach's alfa \\
\hline Şiddete Yönelik Düşünce ve Eylem Eğilimi & 8 &, 82 \\
\hline Kurumsal Aidiyet & 5 &, 77 \\
\hline Futbol Taraftarı Fanatiklik Ölçeği & 13 &, 84 \\
\hline Takıma Destek Motivasyonu & 8 &, 91 \\
\hline Takımla Özdeşleşme Motivasyonu & 4 &, 75 \\
\hline Kullanım Hazzı Motivasyonu & 4 &, 93 \\
\hline Sosyal Cazibe Motivasyonu & 4 &, 78 \\
\hline Alışveriş Hazzı & 3 &, 87 \\
\hline Lisanslı Ürün Satın Alma Ölçeği & 23 &, 95 \\
\hline
\end{tabular}

Tablo 1'de Futbol Taraftarı Fanatiklik ve Lisanslı Ürün Satın Alma Ölçeğine ait alt boyutların iç tutarlılık değerleri verilmiştir. Futbol Taraftarı Fanatiklik Ölçeğine ait alt boyutlar Şiddete Yönelik Düşünce ve Eylem Eğilimi $\alpha=0.82$, Kurumsal Aidiyet ise $\alpha=0.77$ olarak bulunmuştur. Toplam ölçeğin iç tutarlılık değeri ise $\alpha=0.84$ bulunmuştur. Lisanslı Ürün Satın Alma Ölçeğine ait Takıma Destek Motivasyonu alt boyutunun $\alpha=0.91$, Takımla Özdeşleşme Motivasyonu alt boyutunun $\alpha=0.75$, Kullanım Hazzı Motivasyonu alt boyutunun $\alpha=0.93$, Sosyal Cazibe Motivasyonu alt boyutunun $\alpha=0.78$ ve Alışveriş Hazzı alt boyutunun ise $\alpha=0.87$ olarak bulunmuştur. Toplam ölçeğin iç tutarlilik değeri ise $\alpha=0.95$ bulunmuştur. 
T ablo 2. Katılımcıların demografik özelliklerine göre dağılımı

\begin{tabular}{|c|c|c|c|}
\hline Değişkenler & & $\mathbf{n}$ & $\%$ \\
\hline \multirow[b]{2}{*}{ Cinsiyet } & Erkek & 149 & 38,7 \\
\hline & Kadın & 236 & 61,3 \\
\hline \multirow[b]{3}{*}{ Yaş } & $17-20$ yaş & 224 & 58,2 \\
\hline & $21-24$ yaş & 132 & 34,3 \\
\hline & 25 yaş ve üzeri & 29 & 7,5 \\
\hline \multirow[b]{3}{*}{ Üniversite } & İstanbul Ü.-Cerrahpaşa & 103 & 26,8 \\
\hline & Acrbadem Üniversitesi & 210 & 54,5 \\
\hline & Esenyurt Üniversitesi & 72 & 18,7 \\
\hline \multirow{5}{*}{ Tuttuğunuz Takım } & Beşiktaş & 89 & 23,1 \\
\hline & Fenerbahçe & 147 & 38,2 \\
\hline & Galatasaray & 121 & 31,4 \\
\hline & Trabzonspor & 10 & 2,6 \\
\hline & Diğer & 18 & 4,7 \\
\hline \multirow{3}{*}{ Futbol Maçlarını Takip Etme Durumu } & Düzenli Takip & 130 & 33,8 \\
\hline & Ara sira & 157 & 40,8 \\
\hline & Takip etmem & 98 & 25,5 \\
\hline \multirow{3}{*}{ Takip Edilen Kitle İletişim Aracı } & Televizyon & 112 & 29,1 \\
\hline & Sosyal Medya & 248 & 64,4 \\
\hline & Bilgisayar & 25 & 6,5 \\
\hline \multirow[b]{2}{*}{ Tuttuğu Takıma Dair Ürün Alma } & Evet & 236 & 61,3 \\
\hline & Hayır & 149 & 38,7 \\
\hline \multirow[b]{2}{*}{ Takımınızı Sosyal Medyadan Takip Ediyor musunuz? } & Evet & 266 & 69,1 \\
\hline & Hayır & 119 & 30,9 \\
\hline \multirow[t]{2}{*}{ Twitter } & Evet & 142 & 36,9 \\
\hline & Hayır & 345 & 63,1 \\
\hline \multirow[t]{2}{*}{ Facebook } & Evet & 78 & 20,3 \\
\hline & Hayır & 307 & 79,7 \\
\hline \multirow[t]{2}{*}{ Instagram } & Evet & 314 & 81,6 \\
\hline & Hayır & 71 & 18,4 \\
\hline \multirow{3}{*}{ Youtube } & Evet & 114 & 29,6 \\
\hline & Hayır & 271 & 70,4 \\
\hline & Toplam & 385 & 100,0 \\
\hline
\end{tabular}

Tablo 2' de katılımcıların kişisel bilgilerine ilişkin istatistiksel bulgulara yer verilmiştir. Analiz sonuçlarına göre; katılımcıların \%61,3'ü “Kadın”, \%58,2'si "17-20 yaş”, “\%54,5'i “Acıbadem Üniversitesi” öğrencisi, \%38,2'si "Fenerbahçe'li" , \%40,8'i maçları "Ara sıra" takip ediyor, "\%64,4'ü "Sosyal Medya'dan", \%61,3'ü “takım ürünü alıyor", \%69,1'i “Sosyal Medyadan" takımların takip etmekte, \%36,9'u “Twitter", \%20,3'ü "Facebook", \%81,6's1 "Instagram" ve \%29,6'sı ise "Youtube" platformlarından takımların takip etmektedir. 
Tablo 3. Futbol Taraftarı Fanatiklik ile Lisanslı Ürün Satın Alma Alt Boyutlarn İlişkisi

\begin{tabular}{|c|c|c|c|c|c|c|c|}
\hline Alt Boyutlar & $\begin{array}{l}\text { Şiddete } \\
\text { Yönelik }\end{array}$ & $\begin{array}{l}\text { Kurumsal } \\
\text { Aidiyet }\end{array}$ & $\begin{array}{l}\text { Takıma } \\
\text { Destek }\end{array}$ & $\begin{array}{l}\text { Takımla } \\
\text { Özdeşleşme }\end{array}$ & $\begin{array}{l}\text { Kullanım } \\
\text { Hazzı }\end{array}$ & $\begin{array}{l}\text { Sosyal } \\
\text { Cazibe }\end{array}$ & $\begin{array}{l}\text { Alışveriş } \\
\text { Hazzı }\end{array}$ \\
\hline Şiddete Yönelik & 1.000 & .352 & .536 & .453 & .500 & .388 & .381 \\
\hline $\mathrm{p}$ & - & .000 & .000 & .000 & .000 & .000 & .000 \\
\hline Kurumsal Aidiyet & & 1000 & .464 & 0.358 & 0.351 & 0.421 & 0.351 \\
\hline $\mathrm{p}$ & & - & .000 & .000 & .000 & .000 & .000 \\
\hline Takıma Destek & & & 1.000 & .636 & 0.710 & .566 & .618 \\
\hline$p$ & & & - & .000 & .000 & .000 & .000 \\
\hline Takımla Özdeşleşme & & & & 1.000 & .628 & .669 & .528 \\
\hline $\mathrm{p}$ & & & & - & .000 & .000 & .000 \\
\hline Kullanim Hazzı & & & & & 1.000 & .436 & .690 \\
\hline $\mathrm{p}$ & & & & & - & .000 & .000 \\
\hline Sosyal Cazibe & & & & & & 1000 & .464 \\
\hline$p$ & & & & & & - & .000 \\
\hline Alışveriş Hazzı & & & & & & & 1.000 \\
\hline $\mathrm{p}$ & & & & & & & - \\
\hline
\end{tabular}

$(\mathrm{p}<0,01)$

Tablo 3'de Futbol taraftarı fanatiklik ve lisanslı ürün satın alma alt boyutları arasında ilişkinin olup olmadığını tespit etmek için $\alpha=0.01$ anlamlılık düzeyinde Sperman Korelasyon testi uygulandı. Test sonuçlarına göre; Şiddete yönelik ile Kurumsal Aidiyet, Takıma Destek, Takımla Özdeşleşme, Kullanım Hazzı, Sosyal Cazibe ve Alışveriş Hazzı alt boyutları arasında istatistiksel olarak anlamlı ilişki olduğu tespit edilmiştir $(\mathrm{p}<0,01)$.

Tablo 4. Katılımcıların cinsiyet değişkenine göre FTFÖ ve LÜSAÖ alt boyutlarn arasındaki farklar

\begin{tabular}{|c|c|c|c|c|c|}
\hline Alt Boyut & Cinsiyet & $\mathbf{N}$ & Sira Ort. & $\mathbf{U}$ & $\mathrm{p}$ \\
\hline \multirow[t]{2}{*}{ Şiddete Yönelik } & Erkek & 149 & 217,54 & & \\
\hline & Kadın & 236 & 177,51 & 13925,500 & ,001 \\
\hline \multirow[t]{2}{*}{ Kurumsal Aidiyet } & Erkek & 149 & 237,92 & & \\
\hline & Kadın & 236 & 164,64 & 10889,500 &, 000 \\
\hline \multirow[b]{2}{*}{ Takıma Destek } & Erkek & 149 & 224,23 & & \\
\hline & Kadın & 236 & 173,28 & 12928,000 &, 000 \\
\hline \multirow[b]{2}{*}{ Takımla Özdeşleşme } & Erkek & 149 & 205,61 & & \\
\hline & Kadın & 236 & 185,04 & 15703,000 & 076 \\
\hline \multirow[b]{2}{*}{ Kullanım Hazzı } & Erkek & 149 & 204,80 & & \\
\hline & Kadın & 236 & 185,55 & 15824,500 & ,096 \\
\hline \multirow[b]{2}{*}{ Sosyal Cazibe } & Erkek & 149 & 217,78 & & \\
\hline & Kadın & 236 & 177,35 & 13889,500 &, 000 \\
\hline \multirow[b]{2}{*}{ Alışveriş Hazzı } & Erkek & 149 & 208,86 & & \\
\hline & Kadın & 236 & 182,99 & 15219,500 &, 025 \\
\hline
\end{tabular}

$(\mathrm{p}<0,05)$ 
Tablo 4' de katılımcların cinsiyetlerine göre futbol taraftarlarının fanatiklik ve lisanslı ürün satın alma durumlarını ölçmek amacıyla Mann Whitney U testi sonuçları verilmiştir. Test sonuçlarına göre; "Şiddete Yönelik", "Kurumsal Aidiyet", "Takıma Destek Motivasyonu", "Sosyal Cazibe" ve "Alı̧veriş Hazzı" alt boyutlarında anlamlı farklılık tespit edilmiştir ( $\mathrm{p}<0.05)$. Erkek katılımcıların "Şiddete Yönelik”, “Kurumsal Aidiyet”, "Takım Destek”, “Sosyal Cazibe" ve "Alışveriş Hazzı" alt boyutlarının sıra ortalamasının kadın katılımcllara göre daha fazla olduğu görülmektedir.

Tablo 5. Katılımcıların yaş değişkenine göre FTFÖ ve LÜSAÖ alt boyutları farklan

\begin{tabular}{|c|c|c|c|c|c|c|}
\hline Alt Boyut & Yaş & $\mathbf{N}$ & Sira Ort. & KW & $\mathrm{p}$ & Post Hoc \\
\hline \multirow{3}{*}{ Şiddete Yönelik } & $17-20$ yaş & 224 & 202,82 & \multirow{3}{*}{9,291} & \multirow{3}{*}{,010 } & \multirow{3}{*}{$3>1$} \\
\hline & $21-24$ yaş & 132 & 188,63 & & & \\
\hline & 25 yaş ve üzeri & 29 & 137,07 & & & \\
\hline \multirow{3}{*}{ Kurumsal Aidiyet } & $17-20$ yaş & 224 & 177,56 & \multirow{3}{*}{21,366} & \multirow{3}{*}{,000 } & \multirow{3}{*}{$2>3,1>2$} \\
\hline & $21-24$ yaş & 132 & 228,10 & & & \\
\hline & 25 yaş ve üzeri & 29 & 152,48 & & & \\
\hline \multirow{3}{*}{ Takıma Destek } & $17-20$ yaş & 224 & 187,63 & \multirow{3}{*}{1,251} & \multirow{3}{*}{, 535} & \\
\hline & $21-24$ yaş & 132 & 200,42 & & & \\
\hline & 25 yaş ve üzeri & 29 & 200,71 & & & \\
\hline \multirow{3}{*}{ Takımla Özdeşleşme } & $17-20$ yaş & 224 & 189,27 & \multirow{3}{*}{1,804} & \multirow{3}{*}{,406 } & \\
\hline & $21-24$ yaş & 132 & 193,71 & & & \\
\hline & 25 yaş ve üzeri & 29 & 218,53 & & & \\
\hline \multirow[b]{3}{*}{ Kullanım Hazzı } & $17-20$ yaş & 224 & 201,76 & \multirow{3}{*}{3,531} & \multirow{3}{*}{,171 } & \\
\hline & 21-24 yaş & 132 & 179,14 & & & \\
\hline & 25 yaş ve üzeri & 29 & 188,38 & & & \\
\hline \multirow[b]{3}{*}{ Sosyal Cazibe } & $17-20$ yaş & 224 & 180,76 & \multirow{3}{*}{6,767} & \multirow{3}{*}{, 034} & \multirow{3}{*}{$1>2$} \\
\hline & $21-24$ yaş & 132 & 211,81 & & & \\
\hline & 25 yaş ve üzeri & 29 & 201,95 & & & \\
\hline \multirow[b]{3}{*}{ Alışveriş Hazzı } & $17-20$ yaş & 224 & 198,92 & \multirow{3}{*}{1,656} & \multirow{3}{*}{,437 } & \\
\hline & $21-24$ yaş & 132 & 183,32 & & & \\
\hline & 25 yaş ve üzeri & 29 & 191,36 & & & \\
\hline
\end{tabular}

$(\mathrm{p}<0,05)$

Tablo 5'de katılımcıların yaşlarına göre futbol taraftarlarının fanatiklik ve lisanslı ürün satın alma durumlarını ölçmek amacıyla Kruskal Wallis testi sonuçları verilmiştir. Test sonuçlarına göre; "Şiddete Yönelik", "Kurumsal Aidiyet" ve "Sosyal Cazibe" alt boyutlarında anlamlı farklılık tespit edilmiştir. ( $\mathrm{p}<0.05)$. 17-20 yaş aralığındaki katılımcıların "Şiddete Yönelik", "21-24 yaş" katılımciları "Kurumsal Aidiyet" ve "Sosyal Cazibe" alt boyutlarının sira ortalamasının diğer katılımcılara göre daha fazla olduğu görülmektedir. 
Tablo 6. Katılımcılarn üniversite değişkenine göre FTFÖ ve LÜSAÖ alt boyutları arasındaki farklar

\begin{tabular}{|c|c|c|c|c|c|c|}
\hline Alt Boyut & Üniversite & $\mathbf{N}$ & Sira Ort. & KW & $\mathrm{p}$ & Post Hoc \\
\hline \multirow{3}{*}{$\begin{array}{l}\text { Şiddete } \\
\text { Yönelik }\end{array}$} & İstanbul & 103 & 169,57 & \multirow{3}{*}{10,519} & \multirow{3}{*}{,005 } & \multirow{3}{*}{$1>2$} \\
\hline & Acibadem & 210 & 209,57 & & & \\
\hline & Esenyurt & 72 & 178,18 & & & \\
\hline \multirow{3}{*}{$\begin{array}{l}\text { Kurumsal } \\
\text { Aidiyet }\end{array}$} & İstanbul & 103 & 252,47 & \multirow{3}{*}{131,484} & \multirow{3}{*}{,000 } & \multirow{3}{*}{$1>2,2>3$} \\
\hline & Acibadem & 210 & 134,29 & & & \\
\hline & Esenyurt & 72 & 279,15 & & & \\
\hline \multirow{3}{*}{$\begin{array}{l}\text { Takıma } \\
\text { Destek }\end{array}$} & İstanbul & 103 & 185,47 & \multirow{3}{*}{7,020} & \multirow{3}{*}{,030 } & \multirow{3}{*}{$2>3$} \\
\hline & Acibadem & 210 & 185,96 & & & \\
\hline & Esenyurt & 72 & 224,29 & & & \\
\hline \multirow{3}{*}{$\begin{array}{l}\text { Takımla } \\
\text { Özdeş- } \\
\text { leşme }\end{array}$} & İstanbul & 103 & 180,61 & \multirow{3}{*}{4,791} & \multirow{3}{*}{,091 } & \\
\hline & Acibadem & 210 & 190,81 & & & \\
\hline & Esenyurt & 72 & 217,10 & & & \\
\hline \multirow{3}{*}{$\begin{array}{l}\text { Kullanım } \\
\text { Hazzı }\end{array}$} & İstanbul & 103 & 178,13 & \multirow{3}{*}{2,885} & \multirow{3}{*}{ 236 } & \\
\hline & Acibadem & 210 & 196,18 & & & \\
\hline & Esenyurt & 72 & 205,01 & & & \\
\hline \multirow{3}{*}{$\begin{array}{l}\text { Sosyal } \\
\text { Cazibe }\end{array}$} & İstanbul & 103 & 197,44 & \multirow{3}{*}{8,984} & \multirow{3}{*}{, 011} & \multirow{3}{*}{$2>3$} \\
\hline & Acıbadem & 210 & 179,98 & & & \\
\hline & Esenyurt & 72 & 224,63 & & & \\
\hline \multirow{3}{*}{$\begin{array}{l}\text { Alışveriş } \\
\text { Hazzı }\end{array}$} & İstanbul & 103 & 179,45 & \multirow{3}{*}{3,495} & \multirow{3}{*}{,174 } & \\
\hline & Acrbadem & 210 & 193,40 & & & \\
\hline & Esenyurt & 72 & 211,20 & & & \\
\hline
\end{tabular}

$(\mathrm{p}<0,05)$

Tablo 6' da katılımcların üniversitelerine göre futbol taraftarlarının fanatiklik ve lisanslı ürün satın alma durumlarını ölçmek amacıyla Kruskal Wallis testi sonuçları verilmiştir. Test sonuçlarına göre; "Şiddete Yönelik”, "Kurumsal Aidiyet", "Takıma Destek" ve "Sosyal Cazibe" alt boyutlarında anlamlı farklılık tespit edilmiştir ( $p<0.05)$. Acıbadem Üniversitesi'nde öğrenim gören katılımcıların "Şiddete Yönelik", Esenyurt Üniversitesi'nde öğrenim gören katılımcıların "Kurumsal Aidiyet", "Takıma Destek" ve "Sosyal Cazibe" alt boyutlarının sıra ortalamasının diğer katılımcılara göre daha fazla olduğu görülmektedir. 
Tablo 7. Katılımcıların takım değişkenine göre FTFÖ ve LÜSAÖ alt boyutları arasındaki farklar

\begin{tabular}{|c|c|c|c|c|c|c|}
\hline Alt Boyut & Takım & $\mathbf{N}$ & Sira Ort. & KW & $\mathrm{p}$ & Post Hoc \\
\hline \multirow{4}{*}{ Şiddete Yönelik } & Beşiktaş & 89 & 189,33 & \multirow{4}{*}{9,599} & \multirow{4}{*}{, 022} & \multirow{4}{*}{$2>4$} \\
\hline & Fenerbahçe & 147 & 204,79 & & & \\
\hline & Galatasaray & 121 & 194,96 & & & \\
\hline & Diğer & 28 & 134,29 & & & \\
\hline \multirow{4}{*}{ Kurumsal Aidiyet } & Beşiktaş & 89 & 211,31 & \multirow{4}{*}{6,689} & \multirow{4}{*}{083} & \\
\hline & Fenerbahçe & 147 & 196,06 & & & \\
\hline & Galatasaray & 121 & 184,92 & & & \\
\hline & Diğer & 28 & 153,63 & & & \\
\hline \multirow{4}{*}{ Takıma Destek } & Beşiktaş & 89 & 206,14 & \multirow{4}{*}{4,268} & \multirow{4}{*}{234} & \\
\hline & Fenerbahçe & 147 & 199,13 & & & \\
\hline & Galatasaray & 121 & 181,28 & & & \\
\hline & Diğer & 28 & 169,70 & & & \\
\hline \multirow{4}{*}{ Takımla Özdeşleşme } & Beşiktaş & 89 & 203,66 & \multirow{4}{*}{1,852} & \multirow{4}{*}{ 604 } & \\
\hline & Fenerbahçe & 147 & 195,50 & & & \\
\hline & Galatasaray & 121 & 184,02 & & & \\
\hline & Diğer & 28 & 184,77 & & & \\
\hline \multirow{4}{*}{ Kullanım Hazzı } & Beşiktaş & 89 & 199,31 & \multirow{4}{*}{5,427} & \multirow{4}{*}{143} & \\
\hline & Fenerbahçe & 147 & 201,10 & & & \\
\hline & Galatasaray & 121 & 188,35 & & & \\
\hline & Diğer & 28 & 150,52 & & & \\
\hline \multirow{4}{*}{ Sosyal Cazibe } & Beşiktaş & 89 & 193,24 & \multirow{4}{*}{4,474} & \multirow{4}{*}{,215 } & \\
\hline & Fenerbahçe & 147 & 206,49 & & & \\
\hline & Galatasaray & 121 & 178,38 & & & \\
\hline & Diğer & 28 & 184,63 & & & \\
\hline \multirow{4}{*}{ Alışveriş Hazzı } & Beşiktaş & 89 & 187,40 & \multirow{4}{*}{8,817} & \multirow{4}{*}{, 032} & \multirow{4}{*}{$2>4$} \\
\hline & Fenerbahçe & 147 & 206,52 & & & \\
\hline & Galatasaray & 121 & 192,93 & & & \\
\hline & Diğer & 28 & 140,13 & & & \\
\hline
\end{tabular}

$(\mathrm{p}<0,05)$

Tablo 7'de katılımciların tuttuklarımı takımlara göre futbol taraftarlarının fanatiklik ve lisanslı ürün satın alma durumlarını ölçmek amacıyla Kruskal Wallis testi sonuçları verilmiştir. Test sonuçlarına göre; "Şiddete Yönelik" ve "Alışveriş Hazzı" alt boyutlarında anlamlı farklılık tespit edilmiştir ( $\mathrm{p}<0.05)$. Fenerbahçe takım taraftarlarının "Şiddete Yönelik" ve "Alışveriş Hazzı" alt boyutlarının sıra ortalaması diğer takım taraftarlara göre daha fazla olduğu görülmektedir. 
Tablo 8. Katılımcıların maçlan takip etme değişkenine göre FTFÖ ve LÜSAÖ alt boyutlan arasindaki farklar

\begin{tabular}{|c|c|c|c|c|c|c|}
\hline Alt Boyut & Takip Etme & $\mathbf{N}$ & Sira Ort. & KW & $\mathrm{p}$ & Post Hoc \\
\hline \multirow{3}{*}{ Şiddete Yönelik } & Düzenli & 130 & 239,35 & \multirow{3}{*}{60,525} & \multirow{3}{*}{, $000^{*}$} & \multirow{3}{*}{$1>2,2>3,1>3$} \\
\hline & Ara sira & 157 & 197,63 & & & \\
\hline & Takip Etmem & 98 & 124,09 & & & \\
\hline \multirow{3}{*}{ Kurumsal Aidiyet } & Düzenli & 130 & 254,72 & \multirow{3}{*}{81,182} & \multirow{3}{*}{, $000^{*}$} & \multirow{3}{*}{$1>2,2>3,1>3$} \\
\hline & Ara sıra & 157 & 186,47 & & & \\
\hline & Takip Etmem & 98 & 121,59 & & & \\
\hline \multirow{3}{*}{ Takıma Destek } & Düzenli & 130 & 264,23 & \multirow{3}{*}{96,527} & \multirow{3}{*}{, $000^{*}$} & \multirow{3}{*}{$1>2,2>3,1>3$} \\
\hline & Ara sira & 157 & 178,62 & & & \\
\hline & Takip Etmem & 98 & 121,54 & & & \\
\hline \multirow{3}{*}{ Takımla Özdeşleşme } & Düzenli & 130 & 233,98 & \multirow{3}{*}{31,073} & \multirow{3}{*}{, $000^{*}$} & \multirow{3}{*}{$1>2,1>3$} \\
\hline & Ara sira & 157 & 183,25 & & & \\
\hline & Takip Etmem & 98 & 154,25 & & & \\
\hline \multirow{3}{*}{ Kullanım Hazzı } & Düzenli & 130 & 247,27 & \multirow{3}{*}{72,748} & \multirow{3}{*}{, $000^{*}$} & \multirow{3}{*}{$1>2,2>3,1>3$} \\
\hline & Ara sira & 157 & 192,93 & & & \\
\hline & Takip Etmem & 98 & 121,12 & & & \\
\hline \multirow{3}{*}{ Sosyal Cazibe } & Düzenli & 130 & 227,55 & \multirow{3}{*}{21,793} & \multirow{3}{*}{, $000^{*}$} & \multirow{3}{*}{$1>2,1>3$} \\
\hline & Ara sira & 157 & 184,20 & & & \\
\hline & Takip Etmem & 98 & 161,28 & & & \\
\hline \multirow[t]{3}{*}{ Alışveriş Hazzı } & Düzenli & 130 & 231,95 & \multirow{3}{*}{47,847} & \multirow{3}{*}{, $000^{*}$} & \multirow{3}{*}{$1>2,2>3,1>3$} \\
\hline & Ara sira & 157 & 199,70 & & & \\
\hline & Takip Etmem & 98 & 130,60 & & & \\
\hline
\end{tabular}

$(\mathrm{p}<0,05)$

Tablo 8'de katılımcıların maçları takip etme durumlarına göre futbol taraftarlarının fanatiklik ve lisanslı ürün satın alma durumlarını ölçmek amacıyla Kruskal Wallis testi sonuçları verilmiştir. Test sonuçlarına göre; iki ölçeğe de ait tüm alt boyutlarda anlamlı farklılık tespit edilmiştir $(p<0.05)$. Ayrıca, bu farklılığın, "Düzenli" ve "Ara sıra" takip edenler, "Düzenli" ve "Asla" takip etmeyenler ve "Düzenli" ve "Asla" takip etmeyenler arasinda olduğu belirtilmiştir. Düzenli takip eden katılımcıların "Şiddete Yönelik", "Kurumsal Aidiyet", "Takıma Destek", "Takımla Özdeşleşme”, "Kullanım Hazzı", "Sosyal Cazibe" ve "Alışveriş Hazzı" alt boyutlarının sıra ortalaması diğer katılımcılara göre daha fazla olduğu görülmektedir. 
Tablo 9. Katılımcılarn takip etme araçlarına göre FTFÖ ve LÜSAÖ alt boyutları arasındaki farklar

\begin{tabular}{|c|c|c|c|c|c|c|}
\hline Alt Boyut & Araç & $\mathbf{N}$ & Sira Ort. & KW & $\mathrm{p}$ & Post Hoc \\
\hline \multirow{3}{*}{ Şiddete Yönelik } & Televizyon & 112 & 200,59 & \multirow{3}{*}{1,452} & \multirow{3}{*}{484} & \\
\hline & Sosyal Medya & 248 & 188,08 & & & \\
\hline & Bilgisayar & 25 & 207,82 & & & \\
\hline \multirow{3}{*}{ Kurumsal Aidiyet } & Televizyon & 112 & 222,10 & \multirow{3}{*}{11,396} & \multirow{3}{*}{, 003} & \multirow{3}{*}{$2>3$} \\
\hline & Sosyal Medya & 248 & 179,47 & & & \\
\hline & Bilgisayar & 25 & 196,88 & & & \\
\hline \multirow{3}{*}{ Takıma Destek } & Televizyon & 112 & 211,35 & \multirow{3}{*}{6,728} & \multirow{3}{*}{, 021} & \multirow{3}{*}{$1>2$} \\
\hline & Sosyal Medya & 248 & 182,15 & & & \\
\hline & Bilgisayar & 25 & 218,46 & & & \\
\hline \multirow{3}{*}{ Takımla Özdeşleşme } & Televizyon & 112 & 200,35 & \multirow{3}{*}{2,314} & \multirow{3}{*}{, 314} & \\
\hline & Sosyal Medya & 248 & 187,28 & & & \\
\hline & Bilgisayar & 25 & 216,80 & & & \\
\hline \multirow{3}{*}{ Kullanım Hazzı } & Televizyon & 112 & 217,66 & \multirow{3}{*}{9,881} & \multirow{3}{*}{, 007} & \multirow{3}{*}{$1>2$} \\
\hline & Sosyal Medya & 248 & 179,86 & & & \\
\hline & Bilgisayar & 25 & 212,88 & & & \\
\hline \multirow{3}{*}{ Sosyal Cazibe } & Televizyon & 112 & 212,58 & \multirow{3}{*}{5,436} & \multirow{3}{*}{, 066} & \\
\hline & Sosyal Medya & 248 & 183,51 & & & \\
\hline & Bilgisayar & 25 & 199,42 & & & \\
\hline \multirow{3}{*}{ Alışveriş Hazzı } & Televizyon & 112 & 209,37 & \multirow{3}{*}{4,070} & \multirow{3}{*}{ 131 } & \\
\hline & Sosyal Medya & 248 & 184,62 & & & \\
\hline & Bilgisayar & 25 & 202,82 & & & \\
\hline
\end{tabular}

$(\mathrm{p}<0,05)$

Tablo 9' da katılımcıların sosyal medyayı takip ettikleri araçlara göre futbol taraftarlarının fanatiklik ve lisanslı ürün satın alma durumlarını ölçmek amacıyla Kruskal Wallis testi sonuçları verilmiştir. Test sonuçlarına göre; "Kurumsal Aidiyet", "Takıma Destek" ve "Kullanım Hazzı" alt boyutlarında anlamlı farklılık tespit edilmiştir $(\mathrm{p}<0.05)$. Sosyal medyadan takip eden katılımcların "Kurumsal Aidiyet", Bilgisayardan takip eden katılımciların "Takıma Destek" ve Televizyondan takip eden katılımcıların "Kullanım Hazzı" alt boyutlarının sıra ortalaması diğer katılımcılara göre daha yüksek olduğu görülmektedir.

Tablo 10. Katılımcıların ürün alma değişkenine göre FTFÖ ve LÜSAÖ alt boyutlan arasindaki farklar

\begin{tabular}{|c|c|c|c|c|c|}
\hline Alt Boyut & Ürün Alma & $\mathbf{N}$ & Sira Ort. & $\mathrm{U}$ & $\mathrm{p}$ \\
\hline \multirow[t]{2}{*}{ Şiddete Yönelik } & Evet & 236 & 225,03 & \multirow[t]{2}{*}{10022,000} & \multirow[t]{2}{*}{000} \\
\hline & Hayır & 149 & 142,26 & & \\
\hline \multirow[t]{2}{*}{ Kurumsal Aidiyet } & Evet & 236 & 221,31 & \multirow[t]{2}{*}{10902,000} & \multirow[t]{2}{*}{, 000} \\
\hline & Hayır & 149 & 148,17 & & \\
\hline \multirow[t]{2}{*}{ Takıma Destek } & Evet & 236 & 244,11 & \multirow[t]{2}{*}{5520,000} & \multirow[t]{2}{*}{,000 } \\
\hline & Hayır & 149 & 112,05 & & \\
\hline Takımla Özdeşleşme & Evet & 236 & 222,53 & 10612,000 & , 000 \\
\hline
\end{tabular}




\begin{tabular}{|c|c|c|c|c|c|}
\hline & Hayır & 149 & 146,22 & & \\
\hline \multirow[b]{2}{*}{ Kullanım Hazzı } & Evet & 236 & 242,36 & \multirow[t]{2}{*}{5934,000} & \multirow[t]{2}{*}{,000 } \\
\hline & Hayır & 149 & 114,83 & & \\
\hline \multirow[b]{2}{*}{ Sosyal Cazibe } & Evet & 236 & 215,44 & \multirow[t]{2}{*}{12286,000} & \multirow[t]{2}{*}{,000 } \\
\hline & Hayır & 149 & 157,46 & & \\
\hline \multirow[t]{2}{*}{ Alışveriş Hazzı } & Evet & 236 & 228,19 & \multirow[t]{2}{*}{9277,000} & \multirow[t]{2}{*}{000} \\
\hline & Hayır & 149 & 137,26 & & \\
\hline
\end{tabular}

$(\mathrm{p}<0,05)$

Tablo 10' da katılımcıların ürün alma durumlarına göre futbol taraftarlarının fanatiklik ve lisanslı ürün satın alma durumlarını ölçmek amacıyla Kruskal Wallis testi sonuçları verilmiştir. Test sonuçlarına göre; ölçek alt boyutlarının tümünde anlamlı farklılık tespit edilmiştir $(\mathrm{p}<0.05)$. Ürün alan katılımcıların "Şiddete Yönelik", "Kurumsal Aidiyet", "Takıma Destek", “Takımla Özdeşleşme", "Kullanım Hazzı", "Sosyal Cazibe" ve "Alışveriş Hazzı" alt boyutlarının sıra ortalaması ürün almayan katılımcılara göre daha yüksek olduğu görülmektedir.

Tablo 11. Katılımcılarn sosyal medya kullanım değissenine göre FTFÖ ve LÜSAÖ alt boyutlar arasindaki farklar

\begin{tabular}{|c|c|c|c|c|c|}
\hline Alt Boyut & Sosyal Medya & $\mathbf{N}$ & Sira Ort. & $\mathrm{U}$ & $\mathrm{p}$ \\
\hline \multirow[t]{2}{*}{ Şiddete Yönelik } & Evet & 266 & 219,71 & \multirow[t]{2}{*}{8722,500} & \multirow[t]{2}{*}{,000 } \\
\hline & Hayır & 119 & 133,30 & & \\
\hline \multirow[t]{2}{*}{ Kurumsal Aidiyet } & Evet & 266 & 214,42 & \multirow[t]{2}{*}{10128,000} & \multirow[t]{2}{*}{ 000 } \\
\hline & Hayır & 119 & 145,11 & & \\
\hline \multirow[t]{2}{*}{ Takıma Destek } & Evet & 266 & 226,86 & \multirow[t]{2}{*}{6820,500} & \multirow[t]{2}{*}{,000 } \\
\hline & Hayır & 119 & 117,32 & & \\
\hline \multirow[t]{2}{*}{ Takımla Özdeşleşme } & Evet & 266 & 213,86 & \multirow[t]{2}{*}{10279,000} & \multirow[t]{2}{*}{ 000 } \\
\hline & Hayır & 119 & 146,38 & & \\
\hline \multirow[b]{2}{*}{ Kullanım Hazzı } & Evet & 266 & 225,75 & \multirow{2}{*}{7115,000} & \multirow[t]{2}{*}{ 000 } \\
\hline & Hayır & 119 & 119,79 & & \\
\hline \multirow[b]{2}{*}{ Sosyal Cazibe } & Evet & 266 & 213,49 & \multirow[t]{2}{*}{10375,000} & \multirow[t]{2}{*}{,000 } \\
\hline & Hayır & 119 & 147,19 & & \\
\hline \multirow[t]{2}{*}{ Alışveriş Hazzı } & Evet & 266 & 216,14 & \multirow[t]{2}{*}{9671,000} & \multirow[t]{2}{*}{,000 } \\
\hline & Hayır & 119 & 141,27 & & \\
\hline
\end{tabular}

$(\mathrm{p}<0,05)$

Tablo 11'de katılımcların sosyal medyayı kullanma durumlarına göre futbol taraftarlarının fanatiklik ve lisanslı ürün satın alma durumlarını ölçmek amacıyla Mann Whitney U testi sonuçları verilmiştir. Test sonuçlarına göre; ölçeklerin tüm alt boyutları ile arasında anlamlı farklılık olduğu tespit edilmiştir ( $\mathrm{p}<0.05)$. Sosyal medya kullanan katılımcıların "Şiddete Yönelik”, “Kurumsal Aidiyet", "Takıma Destek", "Takımla Özdeşleşme", "Kullanım Hazzı", “Sosyal Cazibe” ve "Alışveriş Hazzı" alt boyutlarının sıra ortalaması 
sosyal medya kullanmayan katılımcılara göre daha yüksek olduğu görülmektedir.

Tablo 12. Katılimcılarn sosyal medya platformu değişkenine göre FTFÖ ve LÜSAÖ alt boyutlan arasindaki farklar

\begin{tabular}{|c|c|c|c|c|c|c|}
\hline Alt Boyut & Kanallar & & $\mathbf{N}$ & Sira Ort. & $\mathrm{U}$ & $\mathrm{p}$ \\
\hline \multirow{8}{*}{$\begin{array}{l}\text { Şiddete } \\
\text { Yönelik }\end{array}$} & \multirow[t]{2}{*}{ Twitter } & Evet & 142 & 226,51 & \multirow[t]{2}{*}{12495,000} & \multirow[t]{2}{*}{,000 } \\
\hline & & Hayır & 243 & 173,42 & & \\
\hline & \multirow[t]{2}{*}{ Facebook } & Evet & 78 & 244,29 & \multirow[t]{2}{*}{7972,000} & \multirow[t]{2}{*}{,000 } \\
\hline & & Hayır & 307 & 179,97 & & \\
\hline & \multirow[t]{2}{*}{ Instagram } & Evet & 314 & 199,47 & \multirow[b]{2}{*}{9116,500} & \multirow[b]{2}{*}{,016 } \\
\hline & & Hayır & 71 & 164,40 & & \\
\hline & \multirow[t]{2}{*}{ Youtube } & Evet & 114 & 231,90 & \multirow[b]{2}{*}{11012,500} & \multirow[b]{2}{*}{, 000} \\
\hline & & Hayır & 271 & 176,94 & & \\
\hline \multirow{8}{*}{$\begin{array}{l}\text { Kurumsal } \\
\text { Aidiyet }\end{array}$} & \multirow[t]{2}{*}{ Twitter } & Evet & 142 & 222,89 & \multirow[t]{2}{*}{13008,500} & \multirow[t]{2}{*}{,000 } \\
\hline & & Hayır & 243 & 175,53 & & \\
\hline & \multirow[t]{2}{*}{ Facebook } & Evet & 78 & 238,41 & \multirow{2}{*}{8431,000} & \multirow[t]{2}{*}{, 000} \\
\hline & & Hayır & 307 & 181,46 & & \\
\hline & \multirow[t]{2}{*}{ Instagram } & Evet & 314 & 196,14 & \multirow[t]{2}{*}{10160,000} & \multirow[t]{2}{*}{,243 } \\
\hline & & Hayır & 71 & 179,10 & & \\
\hline & Youtube & Evet & 114 & 237,71 & 10349,500 &, 000 \\
\hline & & Hayır & 271 & 174,19 & & \\
\hline & Twitter & Evet & 142 & 238,05 & 10856,000 & ,000 \\
\hline & & Hayır & 243 & 166,67 & & \\
\hline & Facebook & Evet & 78 & 261,41 & 6637,000 &, 000 \\
\hline & & Hayır & 307 & 175,62 & & \\
\hline Takıma & Instagram & Evet & 314 & 201,63 & 8437,500 & ,001 \\
\hline Destek & & Hayır & 71 & 154,84 & & \\
\hline & Youtube & Evet & 114 & 235,86 & 10561,000 & ,000 \\
\hline & & Hayır & 271 & 174,97 & & \\
\hline & Twitter & Evet & 142 & 219,20 & 13532,500 & ,000 \\
\hline & & Hayır & 243 & 117,69 & & \\
\hline Takımla & Facebook & Evet & 78 & 238,94 & 8397,500 &, 000 \\
\hline Özdeş- & & Hayır & 307 & 181,35 & & \\
\hline leşme & Instagram & Evet & 314 & 200,64 & 8748,500 &, 004 \\
\hline & & Hayır & 71 & 159,22 & & \\
\hline & Youtube & Evet & 114 & 221,97 & 12144,000 &, 000 \\
\hline & & Hayır & 271 & 180,81 & & \\
\hline & Twitter & Evet & 142 & 230,45 & 11934,500 & ,000 \\
\hline & & Hayır & 243 & 171,11 & & \\
\hline & Facebook & Evet & 78 & 250,97 & 7451,500 &, 000 \\
\hline & & Hayır & 307 & 178,27 & & \\
\hline Kullanım & Instagram & Evet & 314 & 202,50 & 8163,500 &, 000 \\
\hline Hazzı & & Hayır & 71 & 150,98 & & \\
\hline & Youtube & Evet & 114 & 230,67 & 11153,000 & ,000 \\
\hline & & Hayır & 271 & 177,15 & & \\
\hline & Twitter & Evet & 142 & 213,05 & 14406,000 & ,006 \\
\hline & & Hayır & 243 & 181,28 & & \\
\hline & Facebook & Evet & 78 & 245,02 & 7915,500 &, 000 \\
\hline & & Hayır & 307 & 179,78 & & \\
\hline
\end{tabular}




\begin{tabular}{|c|c|c|c|c|c|c|}
\hline \multirow{4}{*}{$\begin{array}{l}\text { Sosyal } \\
\text { Cazibe }\end{array}$} & \multirow[t]{2}{*}{ Instagram } & Evet & 314 & 198,59 & \multirow[t]{2}{*}{9393,000} & \multirow[t]{2}{*}{,037 } \\
\hline & & Hayır & 71 & 168,30 & & \\
\hline & \multirow[t]{2}{*}{ Youtube } & Evet & 114 & 221,34 & \multirow[t]{2}{*}{12216,000} & \multirow[t]{2}{*}{,001 } \\
\hline & & Hayır & 271 & 181,08 & & \\
\hline \multirow{8}{*}{$\begin{array}{l}\text { Alışveriş } \\
\text { Hazzı }\end{array}$} & \multirow[t]{2}{*}{ Twitter } & Evet & 142 & 223,35 & \multirow[t]{2}{*}{12944,000} & \multirow[t]{2}{*}{,000 } \\
\hline & & Hayır & 243 & 175,27 & & \\
\hline & \multirow[t]{2}{*}{ Facebook } & Evet & 78 & 246,13 & \multirow[t]{2}{*}{7829,000} & \multirow[t]{2}{*}{,000 } \\
\hline & & Hayır & 307 & 179,50 & & \\
\hline & \multirow[t]{2}{*}{ Instagram } & Evet & 314 & 199,88 & \multirow[t]{2}{*}{8987,500} & ,010 \\
\hline & & Hayır & 71 & 162,58 & & \multirow{3}{*}{,000 } \\
\hline & \multirow[t]{2}{*}{ Youtube } & Evet & 114 & 223,89 & \multirow[t]{2}{*}{11925,000} & \\
\hline & & Hayır & 271 & 180,00 & & \\
\hline
\end{tabular}

$(\mathrm{p}<0,05)$

Tablo 12'de katılımcılarının kulüplerini takip ettikleri sosyal medya platformlarına göre futbol taraftarlarının fanatiklik ve lisanslı ürün satın alma durumlarını ölçmek amacıyla Mann Whitney $U$ testi sonuçları verilmiştir. Test sonuçlarına göre; "Kurumsal Aidiyet" alt boyutuna göre "Instagram" platformu arasında anlamlı farklılık tespit edilmemiş, diğer tüm alt boyutlarla sosyal medya platformları arasında anlamlı farklılık tespit edilmiştir $(\mathrm{p}<0.05)$. Twitter, Facebook ve Youtube sosyal medya platformlarını kullanan katılımcıların "Şiddete Yönelik", "Kurumsal Aidiyet”, "Takıma Destek”, “Takımla Özdeşleşme", Instagram sosyal medya platformunu kullanan katılımcıların "Kullanım Hazzı", Facebook kullanan katılımclların "Sosyal Cazibe " alt boyutlarının diğer katılımcılara göre daha yüksek olduğu görülmektedir.

\section{Tartışma ve Sonuç}

Futbol taraftarlarının fanatiklik ve lisanslı ürün satın alma düzeylerini ölçmek amacıyla gerçekleştirdiğimiz bu çalışmada taraftarların farklı sosyo-demografik özelliklere göre fanatiklik ve lisanslı ürün satın alma düzeyleri arasinda değişiklik göstermektedir.

Fanatiklik kavramina bazen olumlu bazen de olumsuz anlamlar yüklenmektedir. Özellikle büyük organizasyonlarda fanatik bireylerin bir araya gelmesi şiddetin ortaya çıkmasına neden olabilmektedir (Suzan vd., 2014). Fanatiklik, bir taraftan takımına çok bağlanmayı, onu ölesiye sevmeyi ifade ederken, diğer taraftan şiddet içerikli aşırı davranışlar sergileyerek sosyal yönden uygun olmayan bir çerçeve olarak ifade edilmektedir (Kazan, 2009). Bu doğrultuda taraftarların kulüplerine bağlı olma dereceleri aynı zamanda 
kulübünün ürünlerini satın almada, maçlarını takip etmede önemli bir etken olarak karşımıza çıkmaktadır.

Yapılan analiz sonuçlarında Tablo 4 incelendiğinde cinsiyet değişkenine göre futbol taraftarı fanatiklik ve lisanslı ürün satın alma ölçeğine ait alt boyutlar arasında anlamlı farklılıklar tespit edilmiş̧ir. Erkek katılımcıların puan ortalamaları kadın katılımcılardan fazla olduğunu görebiliriz. Bu sonuç bize, erkek taraftarların kadınlara göre takımlarına daha bağlı olduğu yanında, kulüp lisanslı ürün alma sürecinde de takımlarına daha fazla katkı sağladığını göstermektedir. Polat ve ark., (2019) tarafından "Futbol Taraftarlarının Takım İmajı, Takım Sadakati ve Takımla Özdeşleşme Düzeylerinin Belirlenmesi" adlı çalışmada erkeklerin kadınlara göre spor olaylarını daha fazla takip ettikleri, kadınların ise daha çok aile ve arkadaşlarıyla zaman geçirdiklerini belirtmektedir. Ayn zamanda Kurak (2019) tarafindan yapılan "Investigation of the Football Fanaticism Levels of Physical Education Teachers" adlı çalışmada futbol taraftarı fanatiklik ölçeğine ait alt boyutlar ile cinsiyet değişkeni arasında anlamlı farklılık ortaya çıkmaktadır. Araştırma sonucu, çalışmamızın sonuçlariyla benzerlik göstermektedir.

Tablo 5 incelendiğinde yaş değişkenine göre katılımcıların futbol taraftarı fanatiklik ve lisanslı ürün satın alma ölçeği alt boyutları arasında daha çok fanatiklik olma durumlarına göre anlamlı farklılıklar ortaya çıktığı görülmektedir. Bu farklılıkların 21-24 yaş grubu ile diğer grupta yer alan katılımcılar arasında gerçekleştiğini söyleyebiliriz. Açak ve vd. (2018) yapılan “Türkiye Futbol Federasyonu 1. Ligindeki Taraftarlarının Fanatiklik Durumlarının İncelenmesi" adlı çalışma sonuçları da bizim çalışmamızla paralellik göstermektedir.

Katılımcıların öğrenim gördükleri üniversiteye göre futbol taraftarı fanatiklik ve lisanslı ürün satın alma durumlarını alt boyutlar çerçevesinde incelediğimizde Tablo 6' da yer alan sonuçlara göre anlamlı farklılıklar tespit edilmiştir. Bu farklılı̆̆ın hangi gruplar arasında olduğunu saptamak için Post Hoc testi yapılmış, fanatiklik ölçeğinde "Kurumsal Aidiyet" alt boyutunda İstanbul Üniversitesi-Cerrahpaşa ve Acıbadem Üniversitesi'nde öğrenim gören öğrenciler arasında olduğu ve Acıbadem Üniversitesi'nde yer alan kattlımcıların puanlarının daha yüksek olduğunu göstermektedir. Lisanslı ürün satın alma ölçeğine ait alt boyutlara baktığımızda "Sosyal Cazibe" alt boyutunda Esenyurt Üniversitesi'nde öğrenim gören katılımcıların puanlarının 
Post Hoc testiyle Acıbadem Üniversitesi'ndeki katılımcılardan daha yüksek olduğunu söyleyebiliriz.

Katılımcıların taraftarı oldukları kulüplere göre fanatiklik ve lisanslı ürün satın alma durumlarını incelediğimiz Tablo 7'deki sonuçlara göre anlamlı farklılıklar tespit edilmiştir. Fanatiklik ölçeğine ait "Şiddete Yönelik" ve lisanslı ürün satın alma ölçeğine ait "Alışveriş Hazzı" alt boyutlarına göre Fenerbahçe kulübüne bağlı taraftarların ortalamalarının daha yüksek olduğu ortaya çıkmaktadır. Kazançoğlu ve Baybars (2016) tarafından yapılan "Lisanslı Spor Ürünlerinin Algılanan Değer Bileşenlerinin Satın Alma Niyeti İle İlişkisi: Türkiye'nin En Büyük Üç Futbol Kulübünün İncelenmesi” adlı çalışmada Fenerbahçe taraftarlarının takımlarına ait ürün alırken kalitesine güvendikleri, fiyata göre iyi kalite sundukları için tercih ettikleri sonucuna ulaşmışlardır. Diğer taraftan Kurak (2020) tarafından yapılan "Lise Öğrencilerinin Futbol Fanatiklik Düzeylerinin İncelenmesi” adlı çalışmada Galatasaray taraftarlarının diğer takım taraftarlarından "Şiddete Yönelik" alt boyut bakımından daha fanatik olduğu sonucuna ulaşılmıştır.

Tablo 8' de verilen bilgiler doğrultusunda maçları takip etme durumlarına göre incelediğimiz fanatiklik ve lisanslı ürün satın alma durumlarına yönelik alt boyutlar arasında anlamlı farklılıklar olduğu tespit edilmiştir. Maçları düzenli olarak takip eden katılımcıların puanları diğer gruplarda yer alan katılımcıların puanlarından yüksek bulunmuştur. Tanyeri (2019)'un yapmış olduğu "Futbol Taraftarı Fanatikliği: Üniversite Öğrencileri Örneği" adlı çalışmanın sonuçları bizim çalışmamızla paralellik göstermektedir. Düzenli olarak maçları takip eden taraftarların takımlarına bağlılıklarının ve lisanslı ürün satın almalarının daha yüksek olabileceğini söyleyebiliriz.

Takımlarını takip ettikleri iletişim araçları bakımından incelediğimiz Tablo 9' daki verilere göre futbol taraftarı fanatiklik ve lisanslı ürün satın alma ölçeğine ait alt boyutlarda anlamlı farklılıklar tespit edilmiştir. Futbol taraftarı fanatiklik ölçeğine ait alt boyutta bilgisayar, lisanslı ürün satın alma açısından ise televizyon iletişim araçları açısından puanların yüksek olduğunu söyleyebiliriz. Tanyeri (2019)'un yapmış olduğu çalışma sonuçları bizim çalışmamızla paralellik göstermektedir.

Çalışmamızda elde ettiğimiz diğer bir sonuç, taraftarların takımlarına bağlı olduğunu göstermek için lisanslı ürün satın almaktadır. Lisanslı ürün satın alan katılımcıların puanı daha yüksek bulunmuş, alt boyutlarla karşılaştırdığımızda da anlamlı farklılıklar tespit edilmiştir. Yıldız ve Açak (2018) 
tarafından yapılan “Lise Öğrencilerinin Futbol Fanatiklik Düzeylerinin İncelenmesi" adlı çalışma sonuçları bizim çalışmamızla paralellik göstermektedir. Aynı zamanda Wang ve ark. (2012) tarafından yapılan "The purchasing impact of fan identification and sports sponsorship" çalı̧̧mada taraftarların takımlarına hayran olma seviyeleri arttıkça satın alma düzeylerinin arttı̆̆ sonucuna ulaşmışlardır.

Tablo 10'da belirtilen sosyal medyadan ürün satın alma durumlarına göre futbol taraftarı fanatikliği ve lisanslı ürün satın alma davranışı alt boyutları arasında anlamlı farklılık tespit edilmiştir. Sosyal medyadan ürün alan katılımcların puanının ürün satın almayan katılımclara oranla daha yüksektir. Özellikle sosyal medya pazarlamasının artmaya başladığı bu dönemde, futbol kulüplerinin Instagram, Twitter ve Facebook gibi sosyal medya platformlardan taraftarlarına özel yapmıs oldukları kampanyalı satışlar taraftarları sosyal medya tüketicisi haline getirmiş ve kulüp gelirlerinin artmasını sağlamıştır. Son olarak taraftarların sosyal medya platformlarına göre fanatiklik ve lisanslı ürün satın alma durumlarını incelediğimizde anlamlı farklılıklar tespit edilmiştir. Özellikle Twitter ve Facebook platformlarının takımlarına destek vermek ve lisanslı ürün satın almada öncelik olduğunu göstermektedir. Sosyal medya platformlarının aynı zamanda tüketicilerin düşüncelerini ifade etme, gelişmeleri takip etme ve yeni çkan lisanslı ürünler hakkında bilgi sahibi olmak için kullandığını söyleyebiliriz. Keskin ve Baş (2015) tarafından yapılan "Sosyal medyanın tüketici davranışları üzerine etkisinin belirlenmesi" adlı çalışmanın sonuçları bizim sonuçlarımızla paralellik göstermektedir. Ayn zamanda Apostolopoulou ve ark. (2012) tarafından yapılan "Consumption and Meanings of Team Licensed Merchandise" adlı çalışmada taraftarların takıma ait lisanslı ürün satın aldıklarında takım ile bağlarının daha da güçlenebileceği sonucuna ulaşmışlardır.

Sonuç olarak taraftarların futbol taraftarlığı fanatiklik ve lisanslı ürün satın alma düzeylerini incelediğimiz araştırmamızda, özellikle cinsiyet, maçları takip etme, lisanslı ürün satın alma değişkenlerinde farklılıkların yüksek olduğunu söyleyebiliriz. Özellikle sosyal medya kanallarının taraftarların lisanslı ürün satın alabilmesinde aktif olarak kullanılması sağlanmalıdır. Taraftarlar takımlarıyla sosyal medya kanalları üzerinden etkileşime geçerek, paylaşımlar yaparak ve izlemiş olduğu müsabakada fotoğraf paylaşımı yaparak bağllıklarını internet ortamında göstermektedir. Sosyal medya kanalları yoluyla taraftarlarla iletişim sıkı bir hale getirilmelidir. Teknoloji çağını 
yaşadığımız bu dönemde iletişim araçlarını kulüpler pazarlama açısından daha aktif kullanması gerekmektedir. Diğer yönden kulüplerin sadece erkek taraftarlara değil kadın ve çocuk taraftarlara yönelik faaliyetlerin yapılması gerekmektedir. Tribünlerde kadın ve çocuk taraftarların sayısının artması, kötü söz, çirkin tezahürat ve olayların azalması yönünde etkili olabileceği düşünülmektedir.

Çalışmamız sadece İstanbul ilinde yer alan taraftarlara yönelik olduğu için çalışmanın Türkiye genelinde de yapılabileceği söylenebilir. Aynı zamanda sonraki çalışmalarda daha fazla taraftar katılımı ve daha farklı takım taraftarları sağlanarak çalışma sonucunda elde ettiğimiz bulgularla karşılaştırma yapılabilir. 


\title{
EXTENDED ABSTRACT
}

\section{Investigation of Fanaticity and Licensed Product Purchase Levels of Football Fans}

\author{
Çağrı İlk - Selçuk Bora Çavuşoğlu - Cemal Güler \\ Acıbadem Mehmet Ali Aydınlar Universtiy, İstanbul University
}

In football literature, the concepts of audience, fans and fanaticism are frequently encountered. The spectator is "the person who does not watch a sports match, but sometimes carefully", and the fan is 'the individual who follows the match of his team intensely by allocating special time'. (Jones, 1997). When we look at the difference between the fanatic and the fan, the fanatics are more attached to their team. Consumer behavior is the decisionmaking process that includes all physical activities such as products and services that individuals think will meet their needs, evaluation, purchasing, use and disposal afterwards (Bozkurt, 2004). In line with this information, the aim of our study is to examine the fanaticism and licensed product purchasing levels of football fans according to their socio-demographic characteristics.

A total of 385 volunteer football fans, $61.3 \%$ (236) females and $38.7 \%$ (149) males, participated in our study using the relational screening model. The universe of our research consists of football fans in Istanbul. The sample is composed of football fans studying at Istanbul University-Cerrahpasa, Acıbadem Mehmet Ali Aydınlar University and Esenyurt University, which have just started education in 2019. Our study consists of two parts. In the first part, a Personal Information Form consisting of 9 questions was applied to the participants. In the second part, "Football Fan Fanaticity Scale" (FTFÖ), which was developed by Tasmektepligil, Cankaya and Tunc (2015) and consisted of 13 items, was prepared as a data collection tool and it was used by Kwon and Armstrong (2002) regarding the factors affecting the purchasing of products. , Ayhan et al. (2017) utilized the "Licensed Product Purchase Scale", which has been appropriately modified. The data obtained in our study were analyzed using the SPSS 25.0 package program. Frequency analysis was performed for descriptive statistical results of demographic characteristics, Mann Whitney U test and Kruskal Wallis, which are nonparametric 
tests, were used for hypothesis tests, and Spearman correlation test and Cronbach alpha reliability tests were used for the relationship between two scale sub-dimensions.

In this study, which was carried out to measure the level of fanaticism and licensed product purchasing of football fans, the levels of fanaticism and licensed product purchases vary according to different socio-demographic characteristics of the fans. When Table 4 was examined in the analysis results, significant differences were found between the sub-dimensions of the scale of football fanaticism and licensed product purchasing according to gender variable. When Table 5 is examined, it is seen that according to the age variable, there are significant differences between the sub-dimensions of the football fanaticism and licensed product purchase scale of the participants according to their status of being more fanatic. Significant differences were determined according to the results in Table 7, where we examine the fanaticism and licensed product purchasing status of the participants according to the clubs they support. In line with the information given in Table 8 , it has been determined that there are significant differences between the sub-dimensions regarding fanaticism and licensed product purchasing status, which we examined according to their following the matches. According to the data in Table 9, where we analyzed the teams in terms of the means of communication they follow, significant differences were found in the sub-dimensions of the scale of football fanaticism and licensed product purchasing.. Another result we got from our study is that fans are buying licensed products to show that they are connected to their team. The scores of the participants who purchased licensed products were found to be higher, and when compared with the sub-dimensions, significant differences were detected. A significant difference was found between the sub-dimensions of football fanaticism and licensed product purchasing behavior according to the status of purchasing products from social media indicated in Table 10. The score of the participants who buy products from social media is higher than the participants who do not buy products.

As a result, we can say that the differences in the variables of gender, following the matches, purchasing licensed products are high in our study, where we examined the football fanaticism and licensed product purchasing levels of the fans. In particular, it should be ensured that social media channels are actively used for fans to purchase licensed products. On the other 
hand, clubs should have activities not only for male fans but also for women and children fans. Our study also said the overall work can be done only in Turkey because it is for the fans located in the provinces of Istanbul. At the same time, it can be compared with the findings we have obtained as a result of the study by providing more fan participation and more different team supporters in subsequent studies.

\section{Kaynakça / References}

Açak M., Düz, S., Karataş, Ö., Karademir ,T., Kurak, K. ve Bayer R. (2018) Türkiye Futbol Federasyonu 1. ligindeki taraftarların fanatiklik durumlarmnn incelenmesi. Atatürk Üniversitesi Beden Eğitimi ve Spor Bilimleri Dergisi, 20.

Akyüz, Z. F. (2009). Marka bağhll̆ğının tüketici satın alma kararnndaki etkisi: Ankara Bölgesi Cep telefonu kullaniclarn üzerine bir araştırma. Yüksek Lisans Tezi, Ankara: Gazi Üniversitesi, Eğitim Bilimler Enstitüsü.

Apostolopoulou, A., Papadimitriou, D., Synowka, D. ve Clark,J.S. (2012). Consumption and meanings of team licensed merchandise. Sport Management and Marketing, 12(1-2), 93-109.

Argan, M. ve Katurc1, H. (2008) Spor pazarlaması. Nobel Yayınları, Ankara

Aslan, R, ve Özbeyaz, A. (2019). Satın alma sürecinde marka bağımlllğı üzerine bir araştırma: Adıyaman Üniversitesi örneği. İnsan ve Toplum Bilimleri Araştırmalarn Dergisi, 8(3), 1967-1990. Retrieved from http://www.itobiad.com/tr/issue/47378/546532

Aydın, A.D., Turgut, M. ve Bayırlı, R. (2007). Spor kulüplerinin halka açlmasını Türkiye'de uygulanan modeller açısından incelenmesi. Ticaret ve Turizm Eğitim Fakültesi Dergisi, 1(1), 59-70.

Ayhan, B., Aktaş, H. ve Çelik F. (2017). Lisanslı taraftar ürünlerinin kullanım motivasyonları: Üniversite öğrencileriüzerine bir araştırma. Gümüşhane Üniversitesi Illetişim Fakültesi Elektronik Dergisi, 5(2),

Bozkurt, İ. (2004). İetişim odakl pazarlama: Tüketiciden müşteri yaratmak. İstanbul: MediaCat Akademi

Böke, K. (2017). Sosyal bilimlerde araştırma yöntemleri. İstanbul:Alfa Yayınları.

Çavuşoğlu, S.B. (2011). Marka yönetimi ve pazarlama stratejileri. Ankara:Nobel Akademik Yayincilik.

Dal, S., Odabaş, İ., Suna, N., Bulgan, Ç. ve Akkaya, S. (2014). Türkiye futbol süper ligi derbi maçı izleyicilerinin öfke ve saldırganlık davranışlarının incelenmesi. İstanbul Üniversitesi Spor Bilimleri Dergisi, 4(1).

Devecioğlu, S. (2017). Sporda yeni yaklaşımlar. Ankara:Gazi Kitabevi, 
Donuk, B. (2019). Tam yol yönetim. İstanbul:Ötüken Neşriyat A.Ş.

Donuk, B. veŞenduran, F.S. (2006). Futbolun anatomisi, Ötüken Neşriyat A.Ş. İstanbul, İkiz, M. (2010). Futbolun tarihsel gelişimi. [Blog yazısı]. Futbolun Ekonomisi. http://www.futbolekonomi.com/index.php/haberler-makaleler/genel/126mete-ikiz/247-futbolun-tairhsel-gelisimi.html adresinden erişilmiştir.

TFF. (t.y). Ülkemizde futbolun doğuşu. https://www.tff.org/default.aspx?pageID=293 adresinden erişilmiştir.

Jones, I. (1997) The origin and maintenance of sports fan identification: A response to Wann et al. (1996). Perceptual and Motor Skills. 85; 257-258.

Kazan, B., (2009). Türkiye'de futbol fanatizm ve şiddet. Mimar Sinan Güzel Sanatlar Üniversitesi, Sosyal Bilimler Enstitüsü, Yüksek Lisans Tezi, 103 sayfa, İstanbul.

Kazançoğlu, İ ve Baybars, M. (2015). Lisanslı spor ürünlerinin algilanan değer bileşenlerinin satın alma niyeti ile ilişkisi: Türkiye'nin en büyük üç futbol kulübünün incelenmesi. Doğuş Üniversitesi Dergisi, 17(1), 51-66

Keskin, S. ve Baş, M. (2015). Sosyal medyanın tüketici davranışları üzerine etkisinin belirlenmesi, Gazi Üniversitesi İktisadi ve İdari Bilimler Fakültesi Dergisi, 17(3), 51-69

Kurak, K. (2020). Lise öğrencilerinin futbol fanatiklik düzeylerinin incelenmesi. Kahramanmaraş Sütçü Imam Üniversitesi Germenica Beden Eğitimi ve Spor Bilimleri Dergisi, 1(1), 28-36

Kurak, K. (2019). Investigation of the football fanaticism levels of physical education teachers. International Journal of Progressive Education, 15(4), 66-72.

Kwon, H. H. ve Armstrong, L. K. (2002). Factors influencing impulse buying of sport team licensed merchandise, Sport Marketing Quarterly, 11(3), 151-163.

Mullin, B., Hardy, S. ve Sutton, W. (1993). Sport marketing. Human Kinetics Publishers, Boston College, 3-7.

Polat, E., Sönmezoğlu, U., Ylldı, K. ve Çoknaz, D. (2019) Determination of the levels of team image, team loyalty and team identification of sports fans. International Journal of Sport, Exercise \& Training Sciences - IJSETS, 5(3), 143-153. DOI: 10.18826/useeabd.592699

Poyraz, H.(2007) Fanatizm, bağlanma ve ahlak. Cogito Üç̧ Aylk Düşünce Dergisi; 53, 2736.

Tanyeri, L. (2019). Futbol taraftarı fanatikliği: Üniversite öğrencileri örneği. Spor Ĕgitim Dergisi, 3(2), 89-97.

Taşmektepligil, M. Y., Çankaya, S. ve Tunç, T., (2015). Futbol Taraftarı fanatiklik ölçeği. Spor ve Performans Araştırmalan Dergisi, 6(1), 41-49.

Tercüman Futbol. (1987). Spor Ansiklopedisi. İstanbul:Tercüman Matbaacllk, Uslu, T., Eroğlu, Y., ve Kasap, H. (ed). (2019). Spor Yönetimi. 5.Basımdan Çeviri, Ed. 
Wang, M.C.H, Jain, M., Cheng, J.M.S ve Aung, G.K.M. (2012). The purchasing impact of fan identification and sports sponsorship. Marketing Intelligence \& Planning, 30(5), 553-565.

Ylldız, H. ve Açak, M. (2018). Lise öğrencilerinin futbol fanatiklik düzeylerinin incelenmesi, İnönü Üniversitesi Eğitim Fakültesi Dergisi, 19(3), 738-748. Doi: 10.17679/inuefd.454735

\section{Kaynakça Bilgisi / Citation Information}

İlk, Ç., Çavuşoğlu S.B. ve Güler, C. (2020). Futbol taraftarlarının fanatiklik ve lisanslı ürün satın alma düzeylerinin incelenmesi. OPUS-Uluslararası Toplum Araştırmaları Dergisi, 16(32), 4784-4808. DOI: 10.26466/opus.726872 